\title{
Service Quality and Product Quality Key to Improve Customer Loyalty
}

Didi Suhendi ${ }^{*}$,

Sabihis ${ }^{2}$,

1,2 Management Study Program, Department of Marketing Management, Al-Khairiyah University, Indonesia

\begin{tabular}{ll}
\hline ARTICLE INFO & ABSTRACT \\
\hline ISSN: 2723-1097 & $\begin{array}{l}\text { This research is motivated by the importance of maintaining customer loyalty for } \\
\text { the survival of the company. This study aims to determine and analyze customer } \\
\text { satisfaction and product quality as keys to increasing customer loyalty. The } \\
\text { population of this study were visitors to the Rava Motorcycle Workshop for one } \\
\text { year, amounting to } 3161 \text { customers where the population data was seen from the }\end{array}$ \\
actual customer entry unit in 2019. Based on Slovin calculations with an error of \\
It is maximum 5 \\
$\begin{array}{l}\text { Service Quality; } \\
\text { Product Quality; }\end{array}$ \\
$\begin{array}{l}\text { The research method used is a survey method with a quantitative approach. Data } \\
\text { collection techniques used in this study are questionnaires, observation and } \\
\text { interviews. The instrument used has been tested for validity and reliability. The } \\
\text { data analysis technique used is the descriptive data analysis technique, multiple } \\
\text { correlation and multiple regression. The results of this study indicate that there is } \\
\text { a positive effect of service quality on customer loyalty and there is a positive effect } \\
\text { of product quality on customer loyalty. In addition, simultaneously that there is a } \\
\text { positive effect of service quality and product quality on customer loyalty. }\end{array}$ \\
\hline
\end{tabular}

\section{Introduction}

Customer loyalty can be interpreted as a customer's commitment to a brand, store, supplier based on a very positive attitude and is reflected in consistent repeat purchases (Tjiptono, 2000). In addition, according to Cant \& Toit (2012) loyalty can be interpreted as an emotional bond with the company by making repeat purchases from time to time and recommending the company to others, even though they have other options. Not only can customer loyalty increase the value in a business, but it can also attract new customers (Beerli et al., 2004). According to Gee et al. (2008), the advantages of customer loyalty are that the cost of maintaining loyal customers is less than the costs incurred to acquire new customers, loyal customers are willing to pay higher costs for a set of products or services offered and loyal customers will act as agents. word of mouth marketing.

Loyalty is a measure of the relationship between customers to a product or service. This measure is able to describe whether or not customers may switch to other brands.

Journal of Business and Management Review Vol. 2 No. 92021 Page 620-633

DOI: $10.47153 /$ jbmr29.2092021

*Corresponding Author

Email address: didi.procurement@gmail.com 
the advantage of customer loyalty is the reduced influence of attacks from competitors from similar companies (Sivadas, \& Baker-Prewitt, 2000). In addition, loyal customers can encourage the development of the company because they often provide ideas or suggestions to the company regarding improving the quality of its services and products and in the end they will not really care about the price because they believe in the services and products and the quality of the company (Rangkuti, 2007). Loyalty is based on the best form of service in the form of a product or service (Taylor, \& Hunter, 2002).

According to Gronholdt, Martensen, and Kristensen, (2000), indicators of customer loyalty include 1) Frequency of service use, 2) Recommending to others, 3) Not interested in using services from other companies, and 4) Loyal to brands. According to Robinette (2001) the factors that influence customer loyalty are 1) the first factor, namely caring, 2) the second factor, namely trust, 3) the third factor, namely protection (length of patronage) and 4) The fourth factor is accumulative satisfaction (overall satisfaction). In addition, according to Dharmmesta (1999) the factors that influence loyalty are 1) price, 2) service, 3) product quality and 4) promotion.

The service quality factor is one of the factors that influence customer loyalty (Wendha, Rahyuda, \& Atmosphere, 2013). Tjiptono (2002) states that service quality is the level of excellence expected and control over the level of excellence to meet customer desires. In line with this statement, Tijptono (2007) defines service/service quality as focusing on efforts to fulfill customer needs and desires, as well as the accuracy of delivery to balance customer expectations. Based on the two definitions related to service quality, it can be understood that there are two important factors that affect service quality, namely the service that consumers expect and the service received or perceived by consumers or perceived results.

Service quality or service quality can be known by comparing consumer perceptions of the real service they receive with the service they actually want on the service attributes of a company (Lubis \& Andayani, 2017). Many dimensions can be used to measure service quality or service quality. Brady and Cronin (2001) measure service quality based on the Multi Model which includes three dimensions, namely the quality of interaction, the quality of the physical environment and the quality of the results. In addition, according to Kotler in Tjiptono (2016), there are five dominant factors or determinants of service quality, namely Tangible, Empathy, Responsiveness, Reliability and Assurance.

The importance of the service quality of a company is the extent to which the service can create the maximum possible level of satisfaction for consumers (Kaihatu, 2008), besides that service quality has an impact on consumers, especially consumer satisfaction and loyalty which will get better (Sinurat, Lumanauw, \& Roring, 2017) ,

621 | P a g e

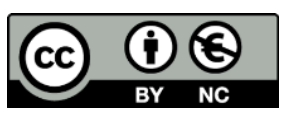

Article's contents are provided on a Attribution-Non Commercial 4.0 Creative commons license. To see the complete license contents, please visit http://creativecommons.org/licenses/by-nc/3.0/ 
and the importance of improving service quality is to create customer satisfaction by making customers the main focus (Rahayu, \& Saryanti, 2014).

Another factor that can affect customer loyalty is product quality ( $\underline{\text { Yuen, \& Chan, }}$ 2010). According to Kotler and Keller (2009), product quality is the totality of features and characteristics of a product or service that depend on its ability to satisfy the stated or implied needs. In addition, product quality is the overall combination of product characteristics resulting from marketing, engineering, production and maintenance that makes the product usable to meet customer or consumer expectations (Bailia, Soegoto, \& Loindong, 2014).

According to Sebastianelli and Tamimi (2002) the dimensions of product quality are divided into eight namely performance, features, reliability, conformance to specifications, durability, service ability, aesthetics. In addition, maintaining product quality is very important because several things including the quality of the products produced can maintain the competitiveness of the product (Santoso, 2016), the importance of maintaining and improving product quality to increase selling value. products (Maknun, 2016) and to achieve the company's vision and mission in generating profit (Setyawan, 2013).

Based on a preliminary study conducted by researchers at the Rava Motorcycle Workshop, the following is the data on the total motor units that have been carried out by the Rava Motorcycle Workshop:

Table 1. Total Motor Units Worked by Rava Motorcycle Workshop in 2019

\begin{tabular}{ccccc}
\hline No & Month & Total Units & Difference & Percentace \\
\hline 1 & January & 211 & - & - \\
2 & February & 265 & 54 & $26 \%$ \\
3 & March & 233 & -32 & $12 \%$ \\
4 & April & 271 & 38 & $16 \%$ \\
5 & May & 306 & 35 & $13 \%$ \\
6 & June & 260 & -46 & $-15 \%$ \\
7 & July & 295 & 35 & $14 \%$ \\
8 & August & 218 & -77 & $-26 \%$ \\
9 & September & 274 & 56 & $26 \%$ \\
10 & October & 302 & 28 & $10 \%$
\end{tabular}

$622 \mid \mathrm{P}$ a g e

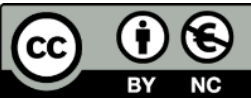

Article's contents are provided on a Attribution-Non Commercial 4.0 Creative commons license. To see the complete license contents, please visit http://creativecommons.org/licenses/by-nc/3.0/ 


\begin{tabular}{ccccc}
\hline No & Month & Total Units & Difference & Percentace \\
\hline 11 & November & 289 & -13 & $-4 \%$ \\
12 & December & 237 & -52 & $-18 \%$ \\
& Total & 3161 & & \\
\hline
\end{tabular}

Source: Rava Motorcycle Workshop, 2019

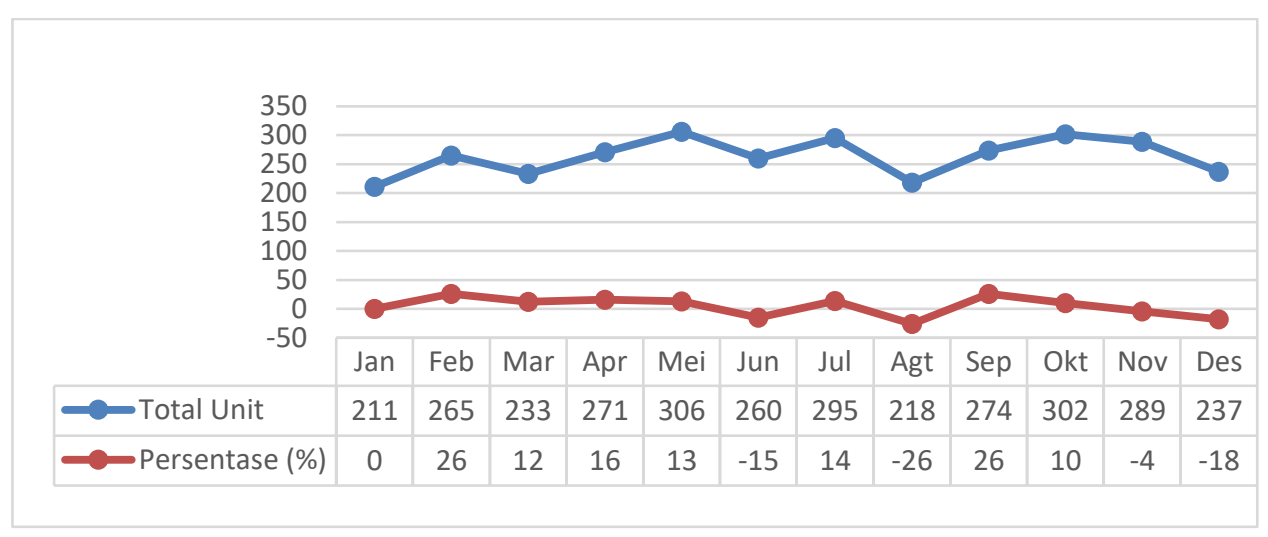

Figure 1. Fluctuations in Rava Motorcycle Workshop Visitors in 2019

From this data, during 2019 it can be seen that the percentage of visitors who performed motorcycle maintenance at the Rava Motorcycle Workshop experienced fluctuating movements. The decline occurred in June, August, November and December. Even though the services provided by the Rava Motorcycle Workshop are good, including fast service for customers who come, friendly employees, providing complete service, adequate and standardized equipment, certified mechanics, quite complete and original spare parts, employee appearance neat and fairly clean workshop.

Several previous studies Damanik, Lubis, \& Siregar, (2010); Hapsari, Clemes, \& Dean, (2017); Huang, Lee, \& Chen, (2019); Lenka, Suar, \& Mohapatra, (2009); Piri, (2013); Riswandi, (2017); Theriady, (2012); Yuen, \& Chan, (2010); support the influence of Service Quality and Product Quality on Customer Loyalty. However, several other studies give different results or gaps regarding customer loyalty.

Based on the background that the researcher describes, the researcher feels the need to conduct a study with the title "Service Quality and Key Product Quality Improving Customer Loyalty". This study aims to determine the analysis of customer satisfaction and product quality as the key to increase customer loyalty.

\section{Literature Review}

623 | P a g e

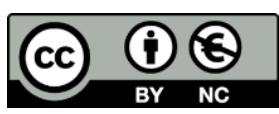

Article's contents are provided on a Attribution-Non Commercial 4.0 Creative commons license. To see the complete license contents, please visit http://creativecommons.org/licenses/by-nc/3.0/ 


\section{Customer Loyalty}

Priansa (2017), defines customer loyalty as a long-term customer commitment that is implemented in the form of loyal behavior and attitudes towards the company and its products by consuming regularly and repeatedly so that the company and its products become an important part of the consumption process carried out by customers. This will affect the existence of the company. Furthermore, Tjiptono and Chandra (2016) state that "customer loyalty is a customer's commitment to a product or service which is reflected in a very positive attitude and a form of repeat purchase behavior made by the customer consistently over the long term. Kotler and Keller (2016) loyal customers have the following characteristics: 1) satisfaction, which is staying with the company as long as expectations are met, 2) repeat purchases, namely returning to the company to buy again, 3) word of mouth, namely putting up their reputation to inform other people about the company, 4) evangelism, which is convincing others to buy the company's products and 5) ownership, which means feeling responsible for the company's success.

\section{Service Quality}

According to Lupiyoadi, Tjiptadi, dan Syah, (2016) service quality is the overall characteristics and characteristics of a product or service in terms of its ability to meet predetermined or latent needs. Meanwhile, Tjiptono and Chandra (2016) define service quality as a measure of how well the level of service provided can match customer expectations. According to Parasuraman in Tjiptono (2016), the factors that affect service quality are expected service (expected service) and perceived service (service received). According to Kotler in Tjiptono (2016), there are five factors, namely 1) tangible, 2) empathy, 3) responsiveness, 4) reliability and 5) certainty/guarantee ( assurance).

\section{Product Quality}

Product quality is a product or service characteristic that relates to its ability to provide satisfaction or meet customer needs. Product quality is the ability of a product to meet consumer desires. These consumer desires include product durability, product reliability, ease of use and other valuable attributes that are free from deficiencies and damage (Tjiptono, 2016). Tjiptono (2016), product quality has eight dimensions as follows: 1) performance (performance) is the main operating characteristic of the purchased core product; 2) features (additional features or characteristics), namely secondary or complementary characteristics, 3) reliability, which is less likely to experience damage or failure to use, 4) conformance to specifications, namely the extent to which the design and operating characteristics meet the standards. determined standards, 5) durability, which is related to how long the product can be

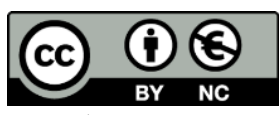

Article's contents are provided on a Attribution-Non Commercial 4.0 Creative commons license. To see the complete license contents, please visit http://creativecommons.org/licenses/by-nc/3.0/ 
used, 6) serviceability including speed, competence, comfort, ease of repair and satisfactory handling of complaints, 7) aesthetics, namely attractiveness product to the five senses, and 8) perceived quality, namely the image and reputation of the product and the company's responsibility towards it.

\section{Method}

This research method uses a survey method through a quantitative approach. The population in this study were visitors to the Rava Motorcycle Workshop for one year, amounting to 3161 customers where the population data was seen from the actual customer entry units in 2019. Based on the calculation of the Slovin formula with a population of 3161 customers and a standard error (e) of $10 \%$, then The number of samples studied was 97 respondents, with the technique of Nonprobability sampling - Incidental Sampling.

Sources of data in this study are primary and secondary data. Primary data were obtained from questionnaires given to customers of Rava Motorcycle Workshop. The secondary data used in this study are journals from related previous studies and workshop bookkeeping records. Data collection techniques in this study were questionnaires, observations and interviews. The instrument used has been tested for validity, reliability and classical assumptions. The data analysis technique used is Multiple Correlation Analysis and Multiple Regression Analysis.

\section{Result and Discussion}

\section{Research Results}

\section{Model Fit (F test and R Square Test)}

Based on the results of data processing using SPSS, the significance value (Sig) of the product quality variable $(\mathrm{X} 2)$ is 0.004 . Because the value of Sig. $0.004<0.05$ probability then it can be concluded that $\mathrm{H} 2$ or the second hypothesis is accepted. This means that there is an effect of product quality (X2) on customer loyalty (Y).

Based on the results of data processing using SPPS, the results of the F (Simultaneous) Test are obtained as follows:

Table 2. F Test

\begin{tabular}{llccccc}
\hline Model & & $\begin{array}{c}\text { Sum of } \\
\text { Squares }\end{array}$ & df & $\begin{array}{c}\text { Mean } \\
\text { Square }\end{array}$ & F & Sig \\
\hline 1 & Regression & 137.745 & 2 & 68.873 & 19.767 & $.000^{\mathrm{b}}$ \\
& Residual & 327.512 & 94 & 3.484 & & \\
& Total & 465.258 & 96 & & & \\
\hline
\end{tabular}

625 | P a g e

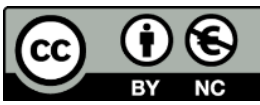

Article's contents are provided on a Attribution-Non Commercial 4.0 Creative commons license. To see the complete license contents, please visit http://creativecommons.org/licenses/by-nc/3.0/ 

a.
b. Dependent Variabel: Customer Loyality
c.
d. Predictors: (Constant), Product Quality, Service Quality
Source: Data Processed by SPSS

\section{The Influence of Service Quality and Product Quality on Customer Loyalty.}

Based on the SPSS output table above, it is known that the calculated F value is 19.767. Because the Fcount $19.767>$ Ftable 3.09, the decision making in the F test can be concluded that the hypothesis (H3) is accepted or in other words, service quality (X1) and product quality (X2) simultaneously affect customer loyalty (Y).

Based on the SPSS "Model Summary" output table above, it is known that the coefficient of determination or R Square is 0.296 or equal to $29.6 \%$. This figure means that the service quality variable $(X 1)$ and product quality variable (X2) affect the customer loyalty variable $(Y)$ by $29.6 \%$. While the rest $(100 \%-29.6 \%=70.4 \%)$ is influenced by other variables outside this regression equation or variables not examined.

Table 3. Coefficient of Determination

\begin{tabular}{lcccc}
\hline Model & R & R Square & Adjusted R Square & Std. Error of Estimete \\
\hline 1 & $.544^{\mathrm{a}}$ & .296 & .281 & 1.867 \\
\hline
\end{tabular}

a. Predictors: (Constant), Product Quality, Service Quality

Source: Data Processed by SPSS

\section{Hypothesis Test Results}

Based on the results of data processing using SPPS, the results of the t-test (Hypothesis) are as follows:

Table 6. T-test (Hypothesis)

\begin{tabular}{ccccccc}
\hline Model & & $\begin{array}{c}\text { Unstandardized } \\
\text { B }\end{array}$ & $\begin{array}{c}\text { Coefficienst } \\
\text { Std. Error }\end{array}$ & $\begin{array}{c}\text { Standardized } \\
\text { Coefficienst } \\
\text { Beta }\end{array}$ & t & Sig \\
\hline 1 & $\begin{array}{c}\text { (Constant) } \\
\text { Service }\end{array}$ & 11.592 & 2.900 & & 3.998 & .000 \\
& $\begin{array}{c}\text { Quality } \\
\text { Product } \\
\text { Quality }\end{array}$ & .081 & .037 & .253 & 2.211 & .029 \\
& & .075 & .343 & 2.995 & .004 \\
& & & & & & \\
\hline
\end{tabular}

a. Dependent Variable: Customer Loyality

Source: Data Processed by SPSS

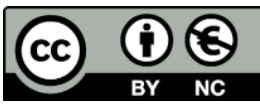

Article's contents are provided on a Attribution-Non Commercial 4.0 Creative commons license. To see the complete license contents, please visit http://creativecommons.org/licenses/by-nc/3.0/ 


\section{The Effect of Service Quality on Customer Loyalty}

Based on the results of data processing using SPSS, the significance value (Sig) of the service quality variable $(X 1)$ is 0.029 . Because the value of Sig. $0.029<0.05$ probability then it can be concluded that $\mathrm{H} 1$ or the first hypothesis is accepted. This means that there is an effect of service quality $(\mathrm{X} 1)$ on customer loyalty $(\mathrm{Y})$.

\section{The Effect of Product Quality on Customer Loyalty}

Based on the results of data processing using SPSS, the significance value (Sig) of the product quality variable $(\mathrm{X} 2)$ is 0.004 . Because the value of Sig. $0.004<0.05$ probability then it can be concluded that $\mathrm{H} 2$ or the second hypothesis is accepted. This means that there is an effect of product quality (X2) on customer loyalty (Y).

\section{The Influence of Service Quality and Product Quality on Customer Loyalty.}

Based on the SPSS output table above, it is known that the calculated F value is 19.767. Because the Fcount $19.767>$ Ftable 3.09, the decision making in the F test can be concluded that the hypothesis (H3) is accepted or in other words, service quality (X1) and product quality (X2) simultaneously affect customer loyalty (Y).

\section{Discussion}

\section{The Effect of Service Quality on Customer Loyalty}

Based on the results of data processing and analysis, it is known that Service Quality has an effect on Customer Loyalty. That is, the higher the quality of service provided by the company, the higher the customer loyalty. Conversely, if the lower the quality of service provided by the company, the lower the loyalty created in the customer. The results of this study are in accordance with Dharmmesta (1999) which states that the factors that influence loyalty are 1) price, 2) service, 3) product quality and 4) promotion.

The results of this study support the results of research including research by Dama (2010) which states that service quality has a positive effect on loyalty, so that a customer is said to have increased loyalty if the customer gets quality service. Furthermore, the results of the same research, namely the research of Putri, \& Utomo, (2017), reveal that the quality of service that is considered good in the eyes of consumers can affect the formation of consumer loyalty to a product or service. The results of the research are also not much different, namely the research of Sawitri, Yasa, \& Jawas, (2013), explaining that service quality has a significant effect on customer loyalty.

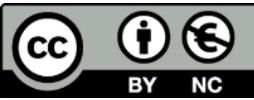


The results of this study are not in line with the results of Aryani, \& Rosinta, (2011), revealing that service quality on customer loyalty does not support their research, because the researchers did not find a significant direct relationship between service quality and customer loyalty. Furthermore, the results of Qomariah (2012) also explain that service quality has no significant effect on student satisfaction and loyalty.

\section{The Effect of Product Quality on Customer Loyalty}

Based on the results of data processing and analysis, it is known that product quality has an effect on customer loyalty. That is, the higher the quality of the product provided by the company, the higher the customer loyalty. Conversely, if the lower the quality of the product provided by the company, the lower the loyalty created in the customer. The results of this study are in accordance with Dharmmesta (1999) which states that the factors that influence loyalty are 1) price, 2) service, 3) product quality and 4) promotion.

The results of this study support the results of research by Lestari, \& Yulianto, E. (2018), revealing that product quality has a significant effect on customer loyalty. Furthermore, the results of research that are not much different, Irawan (2013) examines that product quality affects customer loyalty, which means that product quality affects customer satisfaction or dissatisfaction which will have an impact on customer loyalty. This statement is the same as that stated by Tjiptono, et al (2008), namely the existence of a customer loyalty to an item/service produced by the company, which means that the company's goods/services are of very good quality. So that customers will make repeat purchases that are more than one purchase and will recommend to friends or family.

The results of this study are not in line with the research results of Sembiring (2014), revealing that product quality has no significant effect on customer loyalty. In addition to the results of Hidayat (2009) which states that product quality has no significant effect on customer loyalty, this explains that customers cannot be loyal to the company, if the customer has not felt satisfaction first.

\section{The Influence of Service Quality and Product Quality on Customer Loyalty.}

Based on the results of data processing and analysis, it is known that Service Quality and Product Quality on Customer Loyalty. That is, the higher the Service Quality and Product Quality, the higher the customer loyalty, and vice versa, the lower the Service Quality and Product Quality, the lower customer loyalty. The results of this study are in accordance with the theory of Dharmmesta (1999) which states that the factors that influence loyalty are 1) price, 2) service, 3) product quality and 4) promotion.

628 | P a g e

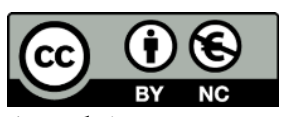

Article's contents are provided on a Attribution-Non Commercial 4.0 Creative commons license. To see the complete license contents, please visit http://creativecommons.org/licenses/by-nc/3.0/ 
The results of this study support the results of previous studies Sussanto, \& Damayanti, (2011); Pongoh, (2013); Basith, (2014); Sembiring, (2014); Saputro, \& Backgrounduva, (2010); Familiar, \& Maftukhah, (2015); Nugroho, (2015); Ardiansyah, (2014); Purba, \& Sulistiono, (2013) which revealed that Service Quality and Product Quality Towards Customer Loyalty.

\section{Conclusion}

Based on the results of data processing and analysis the authors can conclude that: 1) Service quality has a positive effect on customer loyalty, 2) Product quality has a positive effect on customer loyalty and 3) Service quality and product quality have a positive effect on customer loyalty. The implications of this research include: 1) the higher the quality of service will increase customer loyalty and vice versa, so the company must improve the quality of service, 2) the higher the quality of the product will further increase customer loyalty and vice versa so that the company must improve product quality, and 3) the higher the quality of service and product quality, it will further increase customer loyalty so that companies must improve service quality and be balanced with product quality.

Based on the research findings, the authors provide recommendations, namely 1) for the Rava Motorcycle Workshop, the need to increase customer satisfaction by maintaining service quality such as a neat appearance and good communication. Handling problems quickly and accurately by holding knowledge sharing routines to technicians and from the product side in this case spare parts, in order to increase product brand variants, especially genuine spare parts 2) for academics, further research is needed using other variables besides service quality and product quality, because there are $70.4 \%$ of other factors that are very likely to affect loyalty to answer the main problem in this study, namely fluctuations in customer visits. The limitations of this study are only related to service quality and product quality that affect customer loyalty, so that further research can be developed related to other factors that affect customer loyalty such as brand image, customer satisfaction etc.

\section{References}

Ardiansyah, A. (2014). Pengaruh Kualitas Pelayanan Dan Kualitas Produk Terhadap Loyalitas Pelanggan Air Minum Isi Ulang “Biru”(Studi Kasus Pada Masyarakat Ketintang Surabaya). Jurnal Pendidikan Tata Niaga (JPTN), 2(3).

Aryani, D., \& Rosinta, F. (2011). Pengaruh kualitas layanan terhadap kepuasan pelanggan dalam membentuk loyalitas pelanggan. BISNIS $\mathcal{E}$ BIROKRASI: Jurnal Ilmu Administrasi dan Organisasi, 17(2).

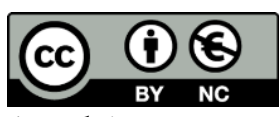

Article's contents are provided on a Attribution-Non Commercial 4.0 Creative commons license. To see the complete license contents, please visit http:/ / creativecommons.org/licenses/by-nc/3.0/ 
Bailia, J. F., Soegoto, A. S., \& Loindong, S. S. R. (2014). Pengaruh kualitas produk, harga dan lokasi terhadap kepuasan konsumen pada warung-warung makan lamongan di kota Manado. Jurnal EMBA: Jurnal Riset Ekonomi, Manajemen, Bisnis dan Akuntansi, 2(3).

Basith, A. (2014). Pengaruh Kualitas Produk dan Kualitas Pelayanan terhadap Kepuasan Pelanggan dan Loyalitas Pelanggan (Survei pada Pelanggan De'Pans Pancake and Waffle di Kota Malang). Jurnal Administrasi Bisnis, 11(1).

Beerli, A., Martin, J. D., \& Quintana, A. (2004). A model of customer loyalty in the retail banking market. European journal of marketing.

Brady, M. K., \& Cronin Jr, J. J. (2001). Some new thoughts on conceptualizing perceived service quality: a hierarchical approach. Journal of marketing, 65(3), 3449.

Cant, M. C., \& du Toit, M. (2012). Identifying the factors that influence retail customer loyalty and capitalising them. International Business \& Economics Research Journal (IBER), 11(11), 1223-1232.

Dama, H. (2010). Pengaruh kualitas pelayanan terhadap loyalitas nasabah pada Bank mandiri Cabang Gorontalo. Jurnal Inovasi, 7(02).

Damanik, K. I., Lubis, E., Siregar, T. R., Nilasari, I., Khairuddin, A., Mufti, N., ... \& Ningsih, S. (2010). Otonomi Daerah, Etnonasionalisme, dan Masa Depan Indonesia: Berapa Persen Lagi Tanah dan Air Nusantara Milik Rakyat. Yayasan Pustaka Obor Indonesia.

Familiar, K., \& Maftukhah, I. (2015). Pengaruh Kualitas Produk dan Kualitas Pelayanan terhadap Loyalitas Pelanggan melalui Kepuasan Pelanggan. Management Analysis Journal, 4(4).

Dharmmesta, B. S. (1999). Loyalitas pelanggan: Sebuah kajian konseptual sebagai panduan bagi peneliti. Jurnal ekonomi dan bisnis Indonesia, 14(3).

Gee, R., Coates, G., \& Nicholson, M. (2008). Understanding and profitably managing customer loyalty. Marketing Intelligence E Planning.

Gronholdt, L., Martensen, A., \& Kristensen, K. (2000). The relationship between customer satisfaction and loyalty: cross-industry differences. Total quality management, 11(4-6), 509-514.

Hapsari, R., Clemes, M. D., \& Dean, D. (2017). The impact of service quality, customer engagement and selected marketing constructs on airline passenger loyalty. International Journal of Quality and Service Sciences.

Hidayat, R. (2009). Pengaruh kualitas layanan, kualitas produk dan nilai nasabah terhadap kepuasan dan loyalitas nasabah Bank Mandiri. Jurnal Manajemen dan kewirausahaan, 11(1), 59-72.

Huang, P. L., Lee, B. C., \& Chen, C. C. (2019). The influence of service quality on customer satisfaction and loyalty in B2B technology service industry. Total Quality Management E Business Excellence, 30(13-14), 1449-1465.

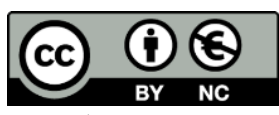

Article's contents are provided on a Attribution-Non Commercial 4.0 Creative commons license. To see the complete license contents, please visit http:/ / creativecommons.org/licenses/by-nc/3.0/ 
Irawan, Deny dan Edwin Japarianto. 2013. Analisa Pengaruh Kualitas Produk

Terhadap Loyalitas Melalui Kepuasan Sebagai Variabel Intervening Pada

Pelanggan Restoran Por Kee Surabya. Surabaya : Jurnal Manjemen Pemasaran

Vol. 1, No. 2 Universitas Kristen Petra.

Kaihatu, T. S. (2008). Analisa kesenjangan kualitas pelayanan dan kepuasan konsumen pengunjung Plaza Tunjungan Surabaya.Jurnal Manajemen dan Kewirausahaan, 10(1), 66-83.

Kotler, Philip dan Kevin Lane Keller. 2009. Manajemen Pemasaran Jilid 1. Edisi Keduabelas. Indeks. Jakarta.

Kotler, P., \& Keller, K. L. (2016). A framework for marketing management (p. 352). Boston, MA: Pearson.

Lenka, U., Suar, D., \& Mohapatra, P. K. (2009). Service quality, customer satisfaction, and customer loyalty in Indian commercial banks. The Journal of Entrepreneurship, 18(1), 47-64.

Lupiyoadi, R., Tjiptadi, A. P., \& Syah, D. O. (2016). Analysis Of Factors Affecting The Use Of E-Commerce On Small and Medium Enterprises (SMEs) Creative Industries in Jabodetabek-Indonesia. In International Conference on Business and Information (p. 30).

Lestari, A., \& Yulianto, E. (2018). Pengaruh Kualitas Produk Terhadap Loyalitas Pelanggan Dengan Kepuasan Pelanggan Sebagai Variabel Mediasi (Survei Pada Pelanggan Citra Kendedes Cake \& Bakery Jl. S. Hatta B3 Kav. A, Kota Malang). Jurnal Administrasi Bisnis, 54(1), 74-81.

Lubis, A. S., \& Andayani, N. R. (2017). Pengaruh kualitas pelayanan (service quality) terhadap kepuasan pelanggan pt. sucofindo batam. Journal of Applied Business Administration, 1(2), 232-243.

Maknun, I. (2016). Peran Kelompok Usaha dan Pemberdayaan Ekonomi Keluarga (KUPEK) Assolahiyah dalam Upaya Menciptakan Kemandirian Masyarakat di Bidang Ekonomi. Jurnal Resolusi Konflik, CSR dan Pemberdayaan (CARE), 1(1).

Nugroho, D. M. (2015). Pengaruh kualitas pelayanan, kualitas produk layanan, dan harga produk layanan terhadap kepuasan pelanggan serta dampaknya terhadap loyalitas pelanggan prabayar telkomsel (Doctoral dissertation, Universitas Mercu Buana).

Qomariah, N. (2012). Pengaruh kualitas layanan dan citra institusi terhadap kepuasan dan loyalitas pelanggan (studi pada universitas muhammadiyah di Jawa Timur). Jurnal aplikasi manajemen, 10(1), 177-187.

Priansa, D. J. (2017). Perilaku konsumen dalam persaingan bisnis kontemporer. Bandung: Alfabeta.

Piri, H. G. (2013). Kualitas pelayanan jasa pengaruhnya terhadap loyalitas pelanggan pada Steiner Salon Manado. Jurnal EMBA: Jurnal Riset Ekonomi, Manajemen, Bisnis dan Akuntansi, 1(4).

631 | P a g e

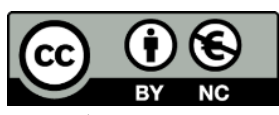

Article's contents are provided on a Attribution-Non Commercial 4.0 Creative commons license. To see the complete license contents, please visit http:/ / creativecommons.org/licenses/by-nc/3.0/ 
Pongoh, M. E. (2013). Kualitas pelayanan, kualitas produk dan harga pengaruhnya terhadap loyalitas pelanggan kartu as telkomsel di kota manado. Jurnal EMBA: Jurnal Riset Ekonomi, Manajemen, Bisnis dan Akuntansi, 1(4).

Purba, J. H. V., \& Sulistiono, S. (2013). Pengaruh Pelayanan dan Kualitas Produk Terhadap Loyalitas Pelanggan. Jurnal Ilmiah Manajemen Kesatuan, 1(1), 85-92.

Putri, Y. L., \& Utomo, H. (2017). Pengaruh Kualitas Pelayanan Terhadap Loyalitas Pelanggan Dengan Kepuasan Sebagai Variabel Intervening (Studi Persepsi Pada Pelanggan Dian Comp Ambarawa). Among Makarti, 10(1).

Rahayu, B. S., \& Saryanti, E. (2014). Pengaruh kualitas pelayanan, hubungan pelanggan dan citra perusahaan terhadap loyalitas melalui kepuasan nasabah. ADVANCE, 1(2).

Rangkuti, F. (2017). Customer care excellence: meningkatkan kinerja perusahaan melalui pelayanan prima plus analisis kasus jasa raharja. Gramedia Pustaka Utama.

Riswandi, E. R. (2017). Pengaruh Kualitas Pelayanan Jasa Dan Kualitas Produk Terhadap Kepuasan Pelanggan Helios Fitness Center Metro Indah Mall (Doctoral dissertation, Universitas Widyatama).

Robinette, S., \& Brand, C. (2001). Emotion marketing: The hallmark way of winning customers for life. McGraw Hill Professional.

Santoso, I. (2016). Peran kualitas produk dan layanan, harga dan atmosfer rumah makan cepat saji terhadap keputusan pembelian dan kepuasan konsumen. The Asian Journal of Technology Management, 15(1), 94.

Saputro, R., \& LATARUVA, E. (2010). Analisis pengaruh kualitas produk, kualitas pelayanan, dan kepercayaan pelanggan terhadap loyalitas pelanggan (studi pada PT. Nusantara Sakti Demak) (Doctoral dissertation, UNIVERSITAS DIPONEGORO).

Sawitri, N. P., Yasa, N. N. K., \& Jawas, A. (2013). Pengaruh Kualitas Pelayanan Terhadap Kepuasan dan Loyalitas Pelanggan Tegal Sari Accommodation di Ubud. Matrik: Jurnal Manajemen, Strategi Bisnis dan Kewirausahaan.

Sebastianelli, R., \& Tamimi, N. (2002). How product quality dimensions relate to defining quality. International Journal of Quality $\mathcal{E}$ Reliability Management.

Sembiring, I. J. (2014). Pengaruh kualitas produk dan kualitas pelayanan terhadap kepuasan pelanggan dalam membentuk loyalitas pelanggan (Studi pada pelanggan McDonald's MT. Haryono Malang). Jurnal Administrasi Bisnis, 15(1).

Setyawan, B. D. (2013). Pengaruh Kualitas Produk dan Kepercayaan Terhadap Loyalitas Konsumen dengan Kepuasan sebagai Variabel Intervening (Studi pada PDAM Tirta Moedal Semarang) (Doctoral dissertation, Universitas Negeri Semarang).

Sinurat, E. S., Lumanauw, B., \& Roring, F. (2017). Pengaruh inovasi produk, harga, citra merek dan kualitas pelayanan terhadap loyalitas pelanggan mobil suzuki ertiga. Jurnal EMBA: Jurnal Riset Ekonomi, Manajemen, Bisnis dan Akuntansi, 5(2).

Sivadas, E., \& Baker-Prewitt, J. L. (2000). An examination of the relationship between service quality, customer satisfaction, and store loyalty. International Journal of Retail \& Distribution Management.

632 | P a g e

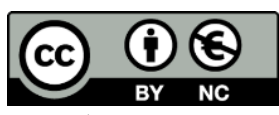

Article's contents are provided on a Attribution-Non Commercial 4.0 Creative commons license. To see the complete license contents, please visit http:/ / creativecommons.org/licenses/by-nc/3.0/ 
Sussanto, H., \& Damayanti, W. (2011). Pengaruh Kualitas Pelayanan dan Produk terhadap Loyalitas Konsumen. Jurnal Ilmiah Ekonomi Bisnis, 13(1).

Taylor, S. A., \& Hunter, G. L. (2002). The impact of loyalty with e-CRM software and e-services. International journal of service industry management.

Theriady, S. (2012). Pengaruh Kualitas Pelayanan Jasa terhadap Loyalitas Pelanggan Provider XL pada Mahasiswa/I Fakultas Ekonomi Jurusan Manajemen di Universitas Kristen Maranatha (Doctoral dissertation, Universitas Kristen Maranatha).

Tjiptono, F. (2000). Manajemen Jasa, Edisi Kedua. Yogyakarta: Andy Offset.

Tjiptono, F. 2007. Strategi Pemasaran. Edisi Kedua. Yogyakarta : Andi Ofset.

Tjiptono, F. (2008). Strategi Pemasaran Edisi 3. Yogyakarta: Andi.

Tjiptono, Fandy. 2016. Pemasaran : Esensi dan Aplikasi. Yogyakarta : Andi.

Tjiptono, F. Gregorius chandra. 2016. Service, Quality \& satisfaction. Yogyakarta. Andi.

Yuen, E. F., \& Chan, S. S. (2010). The effect of retail service quality and product quality on customer loyalty. Journal of Database Marketing $\mathcal{E}$ Customer Strategy Management, 17(3), 222-240.

Wendha, A. A. A. P., Rahyuda, I. K., \& Suasana, I. G. A. K. G. (2013). Pengaruh Kualitas Layanan Terhadap Kepuasan dan Loyalitas Pelanggan Garuda Indonesia di Denpasar. Matrik: Jurnal Manajemen, Strategi Bisnis dan Kewirausahaan. 